Portland State University

PDXScholar

6-1976

\title{
A Descriptive Study of Oregon Literacy Tutors in Multnomah County
}

Marva Schwiebert

Portland State University

Kathleen Whittle

Portland State University

Follow this and additional works at: https://pdxscholar.library.pdx.edu/open_access_etds

Part of the Social Work Commons

Let us know how access to this document benefits you.

\section{Recommended Citation}

Schwiebert, Marva and Whittle, Kathleen, "A Descriptive Study of Oregon Literacy Tutors in Multnomah County" (1976). Dissertations and Theses. Paper 1902.

https://doi.org/10.15760/etd.1901

This Thesis is brought to you for free and open access. It has been accepted for inclusion in Dissertations and Theses by an authorized administrator of PDXScholar. Please contact us if we can make this document more accessible: pdxscholar@pdx.edu. 


\title{
A DESCRIPTIVE STUDY OF OREGON LITERACY \\ TUTORS IN MULTNOMAH COUNTY
}

\author{
by \\ MARVA SCHWIEBERT \\ and. \\ KATHLEEN WHITTLE
}

A report submitted in partial fulfillment of the
requirements for the degree of

MASTER OF SOCIAL WORK

Portland State University June, 1976 


\section{ACKNOWLEDGMENTS}

We wish to acknowledge and thank all the many people at Oregon Literacy, Inc. who graciously answered our many questions, advised us, and provided us with materials and resources.

We wish to thank John Stauffer for granting us permission to quote from The NALA Study. His study served as an invaluable guide in preparing this report.

We also wish to thank Dr. Frank Miles, our advisor, for his guidance, suggestions, and assistance throughout this project.

To Molly, James, and Dan Whittle, Rodney, and Andrew Schwiebert, the five children between us, we express our special thanks. Their maturity and growth has, at times, amazed us. Their cooperation, patience, and willingness to have their needs postponed until the completion of this project has been greatly appreciated. 
TABLE OF CONTENTS

PAGE

\CKNOWLEDGMENTS.........................

LIST OF TABLES.......................... $\quad v$

LIST OF FIGURES.......................... vii

CHAPTER

I INTRODUCTION..................... I

Illiteracy: A Worldwide Problem....... I

Definitions of Illiteracy............ 3

Standards of Literacy.............. 4

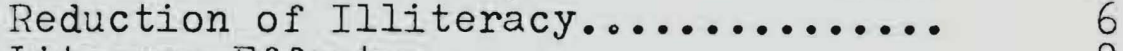

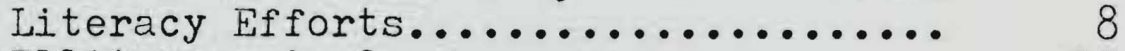

Illiteracy in Oregon............... 10

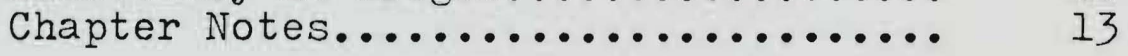

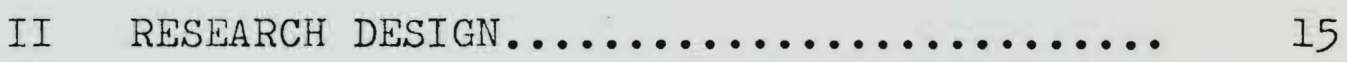

Purposes of the Multnomah Co. Study... 15

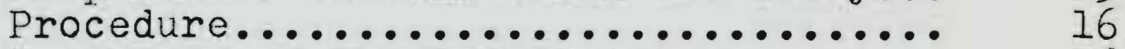

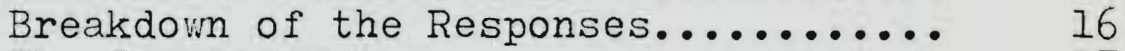

The Questionnaire................. 17

III TUTOR DESCRIPTION: NALA AND MULTNOMAH CO.. $2 I$

Personal Characteristics............ 21

Occupational Characteristics......... 22

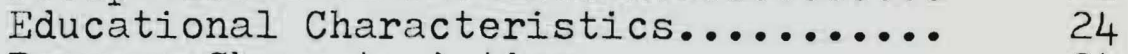

Program Characteristics............ 24

IV TUTORING AND NOT TUTORING VOLUNTEERS . . . . . 27

V DESCRIPTION OF STUDENTS............... 32

Personal Characteristics........... 32

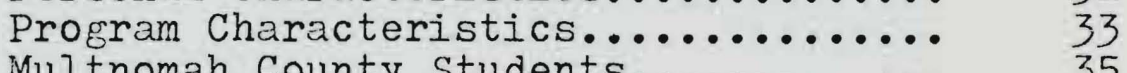

Multnomah County Students.......... 35 
CHAPTER

PAGE

VI PUBLICITY AND TRAINING..............

Publicity.....................

Training.....................

VII RECOMMENDATIONS.................. 


\section{LIST OF TABLES}

TABLE

I Reasons Given by Volunteers Who Have

Tutored in the Past for Not Cur-

rently Tutoring...............

II Reasons Given by Volunteers for Never

Tutoring.

III Reward and Satisfaction as a Volunteer

Tutor.

IV Selected Tutor Characteristics.

V A Comparison of Selected Characteristics

Between Multnomah County Volunteers

Who Are Tutoring Now, Not Tutoring

Now, and who Have Never Tutored....

VI Selected Student Characteristics.......

VII Student Progress and Reasons for Drop-

ping out as Reported by Multnomah

County Tutors.................. 


\section{LIST OF FIGURES}

FIGURE

PAGE

1. Volunteer Interest in Futher Training Opportunities............... 
CHAPTER I

INTRODUCTION

Oregon Literacy, Inc., is a volunteer-based, nonprofit organization working to promote literacy throughout oregon. It was officially founded in 1966. Like many other efforts in literacy it was begun by a small Laubach Committee of pastors and laymen committed to reaching and teaching the illiterate. In the past ten years the effort has expanded to include literacy groups across the state, and Clark and Cowlitz Counties in Washington.

The annual report, July 1, 1974 to June 30, 1975, shows there :ere 674 tutors, teaching 1,082 students. Since the program is based on volunteer tutors this study focuses on those tutors, specifically those in Multnomah County.

\section{Illiteracy: A Norldwide Problem}

Illiteracy is a problem with worldwide dimensions, which has become increasingly important as jet travel, mass media by satellite and multi-national economic development have dra:n our lives closer together.

The history of the movement to eradicate illiteracy on a large scale is comparatively short. The earliest efforts to develop adult literacy were promoted by the Christian Churches. The goal of translating the Bible into languages 
spoken by the people and to teach the people to read so that they might read the scripture themselves, was the primary drivine force. Governmental backing and promotion of literacy as a matter of official policy began in most parts of the world about forty years ago.

The promotion of adult literacy as a governmental enterprise was due largely to the efforts of Dr. Frank Laubach, the "father of literacy". Through his extensive ark in the Philippines Dr. Laubach became convinced that the techniques he had developed could be used by other countries. Over the years he helped construct literacy charts in thirty languages. Promotion of national literacy is now a goal of most governments.

On an international level, the United Nations Educational, Scientific and Cultural Organization (UNESCO) has made illiteracy one of its main concerns. Sir Charles Jeffries outlines the extent of illiteracy as an international problem:

Some two-fifths of the world's adult [aged 15 or more] population--at least 700 million men and women--cannot, at the present time, read and write. Moreover, these 'ililiterates' are not evenly spread about the world but are, for the most part, concentrated in particular areas and countries. A study of the statistics prepared by UNESCO shows, at one end of the scale, a well-defined group of countries (including the U.S., the U.S.S.R., most of the European countries, Canada, Australia, New Zealand and Japan) in which the percentage of illiteracy is insignificant; and at the other end, a group (including most of the countries of Africa and Asia, and several of those of Latin America) in which at 
least half--and in many cases more than threequarters of the adult population are classifiable as illiterate. 1

Eradicating illiteracy has taken on political and economic dimensions in the last two decades.

The original enthusiasm of the Christian missionaries has continued and intensified. It had been reinforced by the zeal of the humanitarian to help men conquer poverty and disease by first conquering ignorance; by the economist's recognition that production and trade cannot expand so long as illiteracy handicaps the peoples of half the world; by the political thinker's realization that peace and international understanding cannot be achieved while nations are divided within themselves and among one another by the unbridged gulf separating the literate from the illiterate.?

\section{Definitions of Illiteracy}

In the review of the literature there were many definitions of illiteracy. These deficitions fall into two categories, the functional and the normative.

Normative definitions are based on educational attainment, according to a standard set by a particular government. For example, in the United States one is considered literate if one reads as well as the average child at the middle of the fourth grade. The completion of a minimum number of years of schooling implies the acquisition of reading and writing skills.

Functional definitions stressed an individual's adjustment to his society. A person was considered literate if he possessed a level of ability sufficient to permit him to

${ }^{I}$ Citations will be found at the end of the chapter. 
function well in his society. The ability, skills and knowledge needed to function well in a complex, industrialized society would, of course, be greater than those needed in a less highly organized and complex society. Throughout the literature the normative and functional definitions were confused and often used interchangeably. For example, the criteria of a minimum number of years of educational attainment is frequently used as a demarcation bet:ween those who are considered literate and illiterate. At the same time all those persons below the minimum standard are spoken of as "functionally illiterate", whether or not they can, in fact, read or write or function effectively within their particular society.

Donlon, McPeek and Chatham point out that:

The functional definition is inherently attractive for illiteracy is a functional deficit. At the present time, however, there simply is no realistic basis on which to determine a functional level for a society as diverse as the United States; to attempt to describe the criteria for using such a definition would be a truly formidable task. 3

\section{Standards of Literacy}

Statistical information is difficult to assess since different countries apply different minimum standards and definitions. In the United States, the completion of five or more years of education is generally accepted as providing the majority of students with minimum literacy skills. This standard is considered inadequate by many literacy experts. 
Five years of education as a standard for literacy was established by Census Bureau information. For many decades the Census sought information about the number of illiterates in the population by defining the term as persons unable to read or mite in any language. In 1940 this direct question was replaced by a question about the number of years of schooling that the individual had completed. To establish a data base a special study was done which discovered that amone individuals who had never attended school, the illiteracy rate was eighty percent. Of those who had as least one year of school, four out of five individuals had managed to acquire at least a minimum knowledge of reading and writing. Amone those who had completed four years of schooling nineteen out of twenty were literate. On the basis of this study, all individuals who had completed more than four years of schooling were considered literate and those with less than five years of schooling could be called "functional illiterates". 4

Based on 1970 Census Bureau data, by this standard there are 9,949 adults over twenty-one years of age in Multnomah County with a fourth grade education or less who could be considered functionally illiterate. 5

It is difficult to determine from Census data the extent of illiteracy in the United States. The 1971 Census Survey of Educational Attainment found 5.8 million Americans fourteen and older with less than a fifth grade education. This was 3.9 percent of the population over age 13.6 When 
comparisons are made with other countries the United States is quoted as having an official illiteracy rate of one percent.? John M. Stauffer points out when looking at such a statistic one may be tempted to consider illiteracy in the United States as insignificant. However, literacy is a matter of degree as well as number and "to the illiterate minority faced vith the multiple intricacies of life in the United States, it can be no less significant." 8

\section{Reduction of Illiteracy}

In 1890 there were more than 6.3 million illiterates in the United States or approximately one out of every seven persons could not read or write in any language. The reduction of illiteracy has been primarily due to t:o factors: compulsory education and the drastic reduction of immigration.

Compulsory Education. Compulsory education of children was videspread in the United States by 1900. Jeffries points out that it takes the best part of a century after the introduction of universal primary education before it is possible to say that, with negligible exceptions, every member of the community can read and write. 9 Although school attendance is used as the primary measure of literacy today, this does not guarantee a literate population. Edwin Smith states:

In addition to those who have attended school for only a fe:: years, and in addition to the huge number of functionally illiterate school dropouts, there are thousands of high school graduates from poverty schools who are also functionally illiterate.10 
He estimates that conservatively there are 20,000,000 of these functionally illiterate adolescents and adults in the United States and that about 10,000,000 of these are considered trainable since they have failed to learn to read and write on an adult level due in part to the failure of the educational system.

School attendance as an indicator of literacy would have to take into account variations in state definitions of what constitutes a school year, variations in actual school attendance, variations in the quality of instruction and advancement of a pupil from one grade to the next, irrespective of the mastery of the materials. Il

Smith and Fay report that one in twenty children is held back each year usually because of reading problems. They estimate that eight million school children need special help in learning to read, while teachers estimate that 43 percent of elementary school children are in critical need of reading help.

The economic consequences of failing to become literate are considerable:

If our sorry record of reading deficiency was confined to the educational sector, it would still be a matter of grave national concern. Carried over into the world of work, its economic consequences are staggerinE. ate.

Five miliion job seekers are functionally illiter-

One-third of all job holders are denied advancement because of reading deficiencies. Over 20 million Americans age sixteen and over are unable to read, with understanding, at least 10 percent of the questions on standard application 
forms such as those for a driver's license, a personal loan, or Medicaid.

The functionally illiterate person earns an average of $\$ 4,000$ per year less than the literate person.

It would require 15,000 new teachers and $\$ 100$ million per year to provide reading help to children who need it in all the nation's elementary schools.

In 1970, the Bell System estimated that its companies spent $\$ 25$ million just on basic education for its employees; and the subsidiary of another large company claimed that the cost of training new workers to meet basic literacy requirements would be 3.8 million dollars over a four-year period. I2

Reduction of Immigration. The restriction of immigration in the 1920's and better schooling in their native countries have also served to reduce the rate of illiteracy as the second generations are exposed to public schooling and the older members of the immigrant population die. The recent influx of Vietnamese and Cambodians, particularly to the Northwest, introduces a new focus for local literacy efforts. The Laubach program has responded to this challenge and many of the tutors are now teaching English as a Second Language to this group.

\section{Literacy Efforts}

There are two primary efforts in adult literacy education in the United States today, governmentally sponsored programs and nongovernmental organizations. Adult Basic Education is a governmentally supported effort established by the Economic Opportunity Act of 1964. Adult Basic Education programs were organized on a local level and overseen by the U.S. Office of Education. The guidelines for Adult Basic Education raised the minimum standard for 
functional literacy to the junior high school level, and include communication and mathematical skills. 13

In 1970, President Nixon appointed the National Reading Council and established the "Right to Read" program. This program promotes improvement of in-school reading and has special concern for pre-school children and out of school adolescents and adults. Unlike the Adult Basic Education program, "Right to Read" utilizes volunteer tutors.

The second focus of literacy efforts is the nongovernmental organizations. These organizations are of three basic types: private, church-related, and those receiving Government financial support. 14

The National Affiliation for Literacy Advance (NALA), an affiliate of autonomous literacy councils and individuals With an interest in adult literacy, was founded in 1968 as a membership organization of Laubach Literacy International.

NALA acts as a forum and clearinghouse for information and sets standards for certification of tutors, trainers and writers in literacy projects. NALA today provides a channel for coordinating and exchanging literacy expertise and experience in the United States and Canada.

Oregon Literacy, Inc., is an affiliate of NALA. It is one of twelve states which has a statewide organization to coordinate membership and volunteer literacy programs. Local efforts, such as the Multnomah County program, work through Oregon Literacy in reporting statistics and program development. The advantage of this type of organization 
lies in setting standards for tutor training and certification, sharing of information and distribution of materials. A recent research development which may further the awareness of the extent of illiteracy in the United States is an attempt to construct a general theory of adult functional competency. Begun in 1974 with the establishment of the Adult Performance Level Project at the University of Texas, the objectives of the Adult Performance Level (APL) project are "to specify the competencies of the adult population of the United States."15 The project has broadened the notion of literacy beyond the ability to read and write. The theory recognizes that functional competency is culturebound; consists of a set of skills rather than a static state.

A national assessment of competency has begun. A survey in which the sample data was nationally representative estimates that one-fifth of the U.S. adults are functioning ith difficulty.

The development of an assessment method and a measurable definition of competency can have profound implications for the education of both children and adults in the future.

\section{Illiteracy in Oregon}

The extent of illiteracy in Oregon is difficult to ascertain. Census data measures only the years of schooline which gives some indication of the problem but not the full extent. 
In Multnomah County, the focus of this study, out of a total population of 320,630 adults 25 years and over, there are 9,949 persons who have four years or less of schooling. 16 These figures indicate only a small portion of the problem. They do not include the illiterate under age twenty-five or those who have more years of schooling but are unable to read or write.

Oregon Literacy, Inc., had thirty local literacy projects in 1974-75. The literacy program has grown from teaching five students in 1966 to tutoring over 1,000 in 1974-75. The need for such programs is obviously great and the program has only begun to reach the large number of adults who need tutoring.

The program is based on the Laubach Method of tutoring which was developed specifically for adults. "The aim of the Laubach method is to enable the adult to learn to read the language he speaks as quickly and enjoyably as possible."17 It is based on ten principles:

1. establishing sound-symbol relationships;

2. learning through association rather than rote memory;

3. moving from the known (the spoken word) to the unkno:m (the written word);

4. using words which are in the spoken vocabulary of the adult;

5. use of repetition to strengthen the visual image; 
6. use of meaningful content on an adult interest level;

7. each lesson teaches the adult something new and at the same time reviews previously taught skills;

8. independence in learning--the lessons are selfteaching as far as possible;

9. reading and writing are taught together in the same lesson;

10. the lessons are easy to teach. 18

The material used by the program is The New Streamlined English Series. The Series consists of five skill books and five correlated readers designed to progress the adult from a zero level of literacy to fifth grade level. There is also another book, Everyday Reading and Writing, by Laubach, Kirk and Laubach, for advanced students, which emphasizes the skills needed for reading newspapers, maps, directories, dictionaries, and how to write letters and original stories.

In the following chapters the study will focus on a description of the persons who volunteer their time and energy to tutor illiterate adults, and their students. Since the study is at the request of the agency and in accordance with its present needs, sophistication of research and analysis will be subordinated to the need for a simple, readable account. 
CHAPTER NOTES

${ }^{1}$ Sir Charles Jeffries, Illiteracy: A World Problem (New York: Praeger Publishers, 1967), p. 3 .

2 Jeffries, pp. 13-14.

3 Thomas F. Donlon, W. Miles McPeek, and Lois R. Chatham, Development of the Brief Test of Literacy National Center for Health Statistics, U.S. Dept. of HEW, Series 2, No. 27, March 1968, p. 2 .

${ }^{4}$ Eli Ginzberg and Douglas W. Bray, The Uneducated (New York: Columbia University Press, 1953), pp. 17-18.

5 U.S., Bureau of the Census, General Social and Economic Characteristics: Oregon, 1970 census of Population, Series PC(1)-C39, Feb. 1972, p. 250.

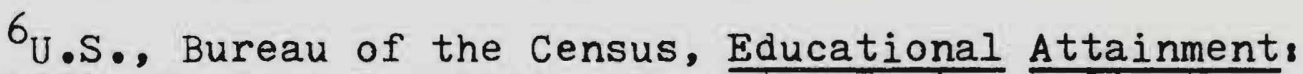
March 1971, Current Population Reports, Series P-20, Dec., 1971, p. 13.

7U.S., Bureau of the Census, Illiteracy in the United States: November 1969, Current Population Reports, Series $\mathrm{P}-20$, No. 217, March 10, 1971, p. 3 .

${ }^{8}$ John M. Stauffer, The NALA Study: A Description of the National Affiliation for Literacy Advance (Syracuse, New York: New Readers Press, 1973), p. 8.

9 Jeffries, p. 6.

10 Edwin H. Smith, Literacy Education for Adolescents and Adults (San Francisco, Cal. Boyd and Fraser Co., 1970), pp. 9-13.

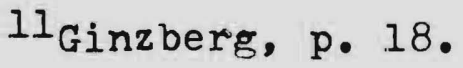

${ }^{12}$ Carl B. Smith and Leo C. Fay, Getting People to Read: Volunteer Programs that Work (New York: Delacorte Press, 1973), p. 2.

13Edwin H. Smith, pp. 10-11.

14 Stauffer, p. 13. 
15W. E. Barron, et al., Adult Functional Competency: A Summary (University of Texas, Austins Division of Extension, March, 1975), p. 2 .

16 General Social and Economic Characteristics: Oregon, p. 250 .

17Frank C. Laubach, Elizabeth M. Kirk, and Robert S. Laubach, The New Streamlined English Series: Teacher's Manual (Syracuse, New York 18Laubach, pp. 5-6. 


\section{CHAPTER II}

\section{RESEARCH DESIGN}

Oregon Literacy, Inc., requested a study of the volunteer tutors in Multnomah County. This study is primarily based on responses to questionnaires sent to all volunteer tutors on the active list with the program in Multnomah County, including all persons who were certified in the training workshops held in 1975.

\section{Purposes of the Multnomah County study}

The purposes of the study were:

1. To compare Multnomah County volunteers with the national profile done by John Stauffer in The NALA Study.

2. To attempt to discover why volunteers have, in their opinions,

a. never tutored.

b. stopped tutoring.

3. To elicit suggestions for

a. improving the program, eg., publicity, training, referrals.

b. recruiting students and volunteer tutors. 
4. To ascertain whether tutors are satisfied with

$$
\text { a. the training. }
$$

\section{Procedure}

Stamped, self-addressed envelopes were included with the questionnaires. Two weeks after the questionnaires were mailed, a systematic attempt was made to telephone the tutors to maximize the response. A large percent of those contacted who had not mailed in their questionnaires were no longer tutoring and had thrown the questionnaires away. A number of those we attempted to contact were no longer at the phone number listed.

\section{Breakdown of the Responses}

One hundred and thirty tutors were certified in 1975 through the tutor training workshops in Portland, Oregon. Twenty six were eliminated because they did not reside in Multnomah County. Fifty did not respond.

There were fifty four responses from the volunteer tutors certified in 1975. Of those:

17 were tutoring now

9 were teaching English as a Second Language (TESL)

19 had never tutored

6 had tutored, but were not tutoring now

3 were tutoring now, but not for Oregon Literacy, Inc.

The remainder of the questionnaires were sent to the tutors certified prior to 1975 who were on the active list. 
Ninety-four questionnaires were mailed to those tutors. Fifty-six did not respond. There were thirty-eight responses from the tutors certified prior to 1975. Of those:

17 were tutoring now

2 were teaching English as a Second Language

19 were not tutoring now.

The Questionnaire

In constructing the questionnaire (see Appendix) we attempted to follow the same categories for selected tutor characteristics as those used by John Stauffer in The NALA Study. This study, done in 1972, established a tutor profile based on a random sample of 1,000 tutors drawn nationwide. The questionnaire was not pre-tested since the majority of the questions had been previously tested in The NALA Study. We wanted other information which was not included in The NALA Study, therefore we included a section in the questionnaire on publicity and another on training. We also included a short section on students, however it is not as comprehensive as the student description in The NALA Study. Tutor Profile. These questions sought personal, occupational and educational information. They also asked for information focusing on the tutor's work as a volunteer. These included the questions, "How did you first hear of volunteer literacy work?" and "What would you say is the main reason you became interested in volunteer literacy work?" Also included in this section were questions seeking 
information on the number of students currently being tutored, the amount of time spent tutoring per week and the total number of students taught in the tutor's entire career. Publicity. The section on publicity was included to elicit suggestions for improving publicity, as well as to Eet tutor's impressions about the publicity of the program. Several questions regarding the listening and reading habits of the tutors were asked to determine if there was a particular pattern to TV viewing and radio listening which might be utilized for reaching potential volunteers. This was not a productive area of exploration since viewing, listening and reading habits varied considerably. The question, "Do you have any suggestions for improving the publicity?" generated a good response with many suggestions.

Training. Five questions were included regarding the the training workshops. The first question, "If you did not complete the training workshop, why not?". was included to eliminate those respondents who were not certified. Only one person answered this question and that questionnaire was eliminated from the sample. The question, "Do you feel that you had enough training to tutor adequately?" elicited a good response. A five-part question about the need for different types of training besides the initial training workshop was apparently confusing to some respondents. Many responded by checking only those items they wanted or did not want rather than responding to all items. This resulted in a varied number of "no data" responses for each category. 
Dividing this question into five separate questions would probably have resulted in a higher response rate. Comments about the training program were also received in the openended questions at the end of the questionnaire.

Students. A short section was included on the students in order to get a picture of the number of students now being tutored and some general information about them. The response to this section was limited since a large number of the respondents to the question were not tutoring now or had never tutored. Those respondents who were teaching English as a Second Language had a large number of students being taught in groups. The agency thought they had eliminated this group of tutors from the mailing list used for this study. Apparently due to the recent influx of Vietnamese and Cambodians many of the regular tutors are now involved in teaching English as a Second Language. Since the data of these students were unrepresentative it is not reported in the section on students' characteristics.

The responses from those tutors teaching English as a Second Language are included in all sections of this report except the short section involving student characteristics. Questions 39 and 40 rely upon the memory of the tutors to estimate the level of Skill Book attainment and reasons for students dropping out of the program. The responses give a generalized picture of student progress and reasons for leaving the program. Question 40, "Please estimate how many of your students dropped out for the following reasons," 
was confusing and a number of responses had to be eliminated. For example, on question 40 one tutor reporting on three past students had five reasons for their dropping out, which implied multiple reasons for leaving the program. The question would have been better designed to allow for multiple reasons, rather than estimating how many students dropped out for a particular reason.

Experience as a Volunteer Tutor. One three-part question was included for the tutors to rate their personal contact with their students, their contact with the program people, and their personal assessment of their tutoring experience. We designed a scale ranging from "very disappointing" to "neutral" to "very rewarding". The tutors were asked to rate their experience by placing a check mark in the section most closely descriptive of their feeling. This verbal scale was translated into a numerical scale for purposes of tabulation. We gave each section a numerical value from one (very disappointing) to ten (very rewarding). A check mark in sections 1 through 4 was considered disappointine to varying degrees. A check mark in sections 5 or 6 was considered a neutral response. A rewarding response was determined by a check mark in sections 7 through 10.

The last two questions, "What could the Laubach proEram do to make tutoring easier for you?" and "Please comment on any changes in the program you would like to see made" elicited a wide variety of comments, most of which were positive statements about the Laubach program. 
CHAPTER III

TUTOR DESCRIPTION: NALA AND MULTNOMAH COUNTY

Rather than compare all the NALA tutor characteristics with the Multnomah County tutor characteristics in the body of this report, we have included the data from The NALA Study in Table IV in the Appendix. Our data was similar in many areas, however there were some striking differences which we will comment on.

The Multnomah County sample differed considerably from the NALA sample in the proportions of sex, age distribution, marital status, number of children living at home, employment status, income distribution and in that there were no Oriental tutors in the NALA sample, in many categories beyond expectations of sampling error. Comparisons, therefore, should be made with caution.

\section{Personal Characteristics}

Sex. There were 17.4 percent male and 82.6 percent female tutors in Multnomah County.

Age. The mean age of tutors in Multnomah County was 50.1 , rith 25.3 percent between the ages of 21 and 30 , and 22 percent between 61 and 70. This sample was overrepresented in the 21-30 years and 61-70 years age brackets and underrepresented in the 41-60 age brackets. 
Ethnic Group. Of those responding to this question, white tutors comprised 96.5 percent of the total. One tutor was black and two were Oriental. There were no American Indian tutors.

Place of Birth. Most tutors, 93.4 percent, were born in the United States. One was born in Canada, three in Europe and two in Asia.

Marital Status. Married tutors comprised over half, 54.4 percent of our sample compared with 75.3 percent of the NALA tutors. Separated or divorced tutors accounted for 7.6 percent of the total. Twenty-six percent were single and 10.9 percent were widowed.

Children Living at Home. Almost three-fourths of the tutors, 72.8 percent, had no children living at home. Those with one child accounted for 8.7 percent, those with two children, 13 percent, three children, 3.3 percent, four, 1.1 percent and five or more children, 1.1 percent.

\section{Occupational Characteristics}

Job Record. The vast majority of the tutors, 92.4 percent, had held a full-time job (at least thirty-five hours a week) at some time. Only 6.5 percent had never worked fulltime.

Current Employment Status. Over one-third of the tutors, 34.8 percent, were working full-time. Another 16.3 percent worked part time, and 4.3 percent were looking for work. In the NALA sample housewives comprised 
40.2 percent of the tutors, whereas housewives in Multnomah County accounted for 9.8 percent of the sample. Retired persons were almost as numerous as those working full-time, with 31.5 percent. Students accounted for 3.3 percent. Job Category. Working tutors comprised 52.1 percent of the sample, or 48 out of 92 . Of the tutors who were working, 43 were employed in professional or technical positions and 23 percent were in clerical positions. Managers and salespersons each comprised 10.4 percent and foremen and service workers each accounted for 6.2 percent.

Prior Experience Teaching Adults. Thirty-six tutors, 39.I percent, had had some experience teaching adults. Of those, 16 had professional experience teaching adults and 20 taught adults in some non-professional capacity.

Teaching Record. In both the NALA sample and the Multnomah County sample 44.6 percent of the tutors had taught some level of school (elementary through college). Type of Current Professional Teaching. Of the 41 certified teachers, 22 were teaching now, or 24 percent of the total sample. Seven were teaching in elementary schools, 5 in adult basic education, two each in special education, secondary schools and English as a Second Language. College, on-the-job instructor, early childhood education and childbirth education each accounted for one teacher.

Personal Income. The median personal income for those reporting fell between $\$ 5,000$ and $\$ 6,999$. 
Family Income. Eighty tutors, 87 percent, reported their family incomes. The greatest number, 24 percent, were in the $\$ 11,000$ to $\$ 15,999$ category. Fifty percent of the sample had incomes above $\$ 11,000$.

Educational Characteristics

Grades Completed. Eighty-four tutors, 91.3 percent, had completed high school. All had completed at least ten years of school.

College Education. Twenty-one tutors, 22.8 percent, had one year or more of college and 38 tutors, 41.3 percent, had completed four years of college.

Graduate Degree. Eighteen tutors, 19.6 percent, had Master's degrees, and one had a seminary degree.

\section{Program Characteristics}

Ho: First Heard of Volunteer Literacy. Fourteen tutors, 15.2 percent, first heard of the volunteer literacy program through church, compared with 32.9 percent of the NALA sample. Hearing about the program from another person accounted for 29.3 percent of the tutors. Twenty-two, 23.9 percent, had read about the literacy program in the newspaper. The rest were almost evenly divided, and first heard about the program through other media, from Frank Laubach or from a literacy organization.

Reasons Tutors Want to Teach. Fifty percent of the tutors stated their main reason for wanting to teach was to 
help others. Self-fulfillment, the enjoyment of teaching, and the importance of reading were all about evenly divided, accounting for 33.7 percent of the sample. In the NALA sample, almost ten percent were religiously motivated, whereas in the Multnomah County sample no one cited a reliGious motivation as their primary reason for wanting to teach others.

Our sample for the following section is seventy-two. The seventeen certified tutors who have never tutored and three who are not tutoring for Oregon Literacy at this time are not included in the following data.

Current Number of Students Per Tutor. Twenty-five tutors, 34.7 percent, were not tutoring at the present time. Most tutors, 44.4 percent, had one student, 5 tutors, 6.9 percent, had two students. Two tutors had three students, 2.8 percent. Three tutors had five or more students, or 4.2 percent of the tutor sample.

Students Taught in Last Year Per Tutor. Thirty-two tutors, 44.4 percent, tutored one student last year and thirteen, 18 percent, tutored two students. The other cateEories from three students to ten or more, all accounted for one or two tutors.

Tutors Career Total of Students. Over half the tutors, 54.2 percent, had taught one student in their entire career, and nine, 12.5 percent had taught two students. Seven tutors had taught from 6 to 10 students, and one had taught over 20 . 
Time as Volunteer Tutor. Tutors who had been tutoring for less than six months accounted for 34.8 percent of the sample. Twenty-five percent had been tutoring for from six months to one year. Eight tutors had been tutoring for two years, three for three years, two for four years, six for five years, and seven for from six to ten years.

\section{Summary of Tutor Characteristics}

The majority of the tutors in both the NALA sample and the Multnomah County sample were married white females with no children living at home. The majority were born in the United States, and their average age was 51.8 in the NALA sample and 50.1 in the Multnomah County sample. Most had :orked full-time at some point in their lives. College sraduates accounted for 52.8 percent of the tutors in the NALA sample and 41.3 percent in Multnomah County. In both samples 44.6 percent had taught school, although 63.2 percent of the tutors in the NALA sample and 59.8 percent in the Multnomah County sample had never had any experience teaching adults prior to volunteering.

The discrepancy between college graduates in Multnomah County ( 42.4 percent) and the number of tutors who "taught school professionally" ( 44.6 percent) exists because we considered the criterion for "college graduate" the highest school grade completed, eg., 16 years. Some tutors were certified as teachers in Normal school before the four year degree was required for teacher certification. 
CHAPTER IV

TUTORING AND NOT TUTORING VOLUNTEERS

One of the purposes of this study is to ascertain why some volunteers are no longer tutoring or have never tutored. We wanted to discover if there were differences between the volunteers who are actively tutoring, those who have stopped tutoring, and those who have never tutored a student.

We chose to examine the characteristics of sex, age, marital status, employment status, number of children living at home, and teaching record to determine if any of these factors had a bearing on tutoring.

Table $V$ in the Appendix shows a comparison between the three groups. There was no significant difference in sex, marital status, number of children living at home, or teaching record. There was a significant difference, by inspection, in mean age. Those volunteers who are actively tutoring are older than both other categories. The mean age for those volunteers tutoring now is 55.4 years, while the mean age for those volunteers who have tutored in the past but are no longer tutoring is 46.6 years. The mean age for those volunteers who have never tutored is 37.2 years. There was also a significantly larger number of retired persons in the "tutoring now" category. These persons \%ould have more time available and more flexible time 
schedules, making it easier to tutor.

We wanted to know why tutors were no longer tutoring if they had tutored in the past. Twenty-six tutors responded to this question. The results are shown in Table I.

\section{TABLE I}

REASONS GIVEN BY VOLUNTEERS WHO HAVE TUTORED IN THE PAST FOR NOT CURRENTLY TUTORING

Reasons

Number of

Too busy with job, family or school Respondents

No new student assigned

12

Student not motivated

Illness in family

Volunteering in other aspects

of the program

Three tutors included in the "too busy" category are currently assigned students but are not presently tutoring by mutual agreement. They plan to resume the program at a later time. Two of these had agreed to take time out for a vacation; one student had job demands.

Those volunteers who had taken a workshop in 1975 but had never tutored were asked why they had never tutored. Seventeen respondents fell into this category.

There were four responses which indicated an interest in tutoring if a student were assigned. Two people said they had lost interest in the program and three have assumed other volunteer work. The results are shown in Table II. 
TABLE II

REASONS GIVEN BY VOLUNTEERS

FOR NEVER TUTORING

\section{Reasons}

Too busy

No student assigned

Had baby

Illness in family

Lost interest or doing other volunteering

Student assigned unable to come
Number of Respondents

3

2

1

5

1

This points to a need for tutoring to begin as soon after the workshop as possible to capitalize on the interest and motivation of the new volunteer. We requested some information about the student assignment process in the question, "After completing the workshop, how soon did you begin tutoring?" Thirty-eight volunteers reported getting a student :ithin one month of completion of the training. This includes three tutors who were already tutoring prior to taking the ::orkshop to become certified. Thirty-four tutors waited over one month before being assigned a student. One tutor reported, with some irritation, that she was assigned her first student seven months after the workshop. Seventeen volunteers have never tutored and three could not recall how soon they had been assigned a student. 
The tutors were asked to rate their experience with the program in three areas: personal contact with the students, the result of their tutoring, and contact with the literacy program staff. The rating was done on a scale ranging from "very disappointing" to "very rewarding". The ratine was given a numerical value for tabulation purposes. A rating from spaces one through four was considered disappointing to various degrees. Five or six was considered neutral, and a rating from seven through ten was considered rewarding. The results are shown in Table III.

\section{TABLE III}

RE:IARD AND SATISFACTION AS A VOLUNTEER TUTOR

\section{A. Personal Contact With Students}

\begin{tabular}{lcccccccc} 
Verbal Scale & \multicolumn{2}{c}{ Disappointing } & Neutral & \multicolumn{2}{l}{ Rewarding } \\
Scale Value & Under & 4 & 5 & 6 & 7 & 8 & 9 & 10 \\
Responses & 3 & 1 & 1 & 2 & 1 & 9 & 20 & 29
\end{tabular}

\section{B. Satisfaction With Program Staff}

Verbal Scale Scale Value

Responses
Disappointing

Under 4,4

01
Neutral 56

34
Rewarding 78910 $\begin{array}{llll}4 & 6 & 16 & 28\end{array}$

\section{Satisfaction With Results of Tutoring}

Verbal scale scale value

Responses
Disappointine

Under $4 \quad 4$

31
Neutral 56

33
Rewarding 78910

$91014 \quad 22$

On the whole, the responses indicated that the majority of the tutors found the experience to be rewarding. There 
was a high degree of satisfaction with contacts with the profram staff. Only one tutor rated the contact as disappointing and seven as neutral, while twenty-eight rated it as very rewarding. This speaks well for the office staff and was borne out by other comments in the questionnaire, such as, "They are alway there if I need them." Only four tutors found their contact with their students to be disappointing and four were also disappointed in their tutoring results. 


\section{CHAPTER V}

\section{DESCRIPTION OF STUDENTS}

Our focus in this study was on the tutors in Multnomah County, however we did include a short section in the questionnaire on the students. In The NALA Study the data on students was collected through the Student Interview with tutors recording all the responses, while our data was received from the Multnomah County tutors who responded to the questionnaire. Our data on students is therefore not as comprehensive as the NALA data and this makes it difficult to compare the two. Stauffer's student description included 509 students, Multnomah County includes 39 students reported by 32 tutors. (See Tables VI and VII in the Appendix.)

\section{Personal Characteristics}

Sex. The sexes were almost evenly divided in both samples, with 259 males and 250 females in the NALA sample, and 19 males and 20 females in Multnomah County's sample. Age. Sixty-five percent of the students in the NALA sample and 69.2 percent of the students in Multnomah County :ere between 21 and 40 years old, with the largest percentages, 33 percent, NALA and 43.6 percent, Multnomah County, falling bet:ieen the ages of 21 and 30. The youngest age range, 16 to 20 years, contained 6.3 percent in the NALA 
sample and 2.1 percent in Multnomah County. The oldest age range, 71 to 80 , accounted for .8 percent in the NALA sample and 5.1 percent in Multnomah County. The student mean age was 35.9 for NALA and 35.2 for Multnomah County.

Ethnic Groups. In the Multnomah County student group nearly three-fourths, 71.8 percent of the students, were white compared with less than half, 45 percent of the NALA sample, however, both samples contained more white students than any other ethnic group. Black students in both samples comprised a little over one-fifth of the students, 23.6 percent in the NALA sample and 21.5 percent in Multnomah County. Only one student in Multnomah County's sample was Spanish American, compared to 128 , or 25.1 percent in NALA's sample. Oriental students were similar in proportion, with 6.3 percent in NALA and 5.1 percent in Multnomah County.

\section{Program Characteristics}

How Students First Heard of Classes. Both nationally and in Multnomah County the greatest number of students heard about the program from friends or relatives. This accounted for 39.7 percent in the NALA study and 35.9 percent in Multnomah County. The mass media accounted for 24 percent nationally and 18 percent in Multnomah County. Eight students in Multnomah County, 7.7 percent, heard of the program from a welfare agency. Two students heard about the profram from someone at a community center. None of the Multnomah County students had heard about the program through 
a school, church or magazine. Nine percent of the students in NALA sample and 12.8 percent in Multnomah County heard about the program through their employer. Teaching Location. Over one-fourth of the students, 29.9 percent NALA, and 28.2 percent, Multnomah County, were taught in their own home. The tutor's home was used by 25.5 percent nationally and 21.6 percent in Multnomah County. Twenty-four percent of the NALA students used a church facility and 10.3 percent in Multnomah County. A significant difference was the 17.9 percent of the students who were tutored at their place of work in Multnomah County compared rith 3.3 percent in the NALA sample. The rest of the students met with their tutors at a community facility, a public school or other public facility such as a library. Number of Classes Per Week. The majority of the NALA students, 55.4 percent, attended one class per week, while another 36.3 percent met twice a week. In Multnomah County 41 percent of the students met once a week and 43.6 percent met twice a week. One Multnomah County student met with the tutor off and on and the others, 12.8 percent, met three times a week. Two percent of the NALA students met three times a week, another 1.2 percent met four to five times per reek.

The follo:ing data is not compared with the NALA sample. We wanted to determine how far most of the past 
students had progressed through the Skill Books and also how far the present students were in their Skill Books.

\section{Multnomah County Students}

Present Student Progress Through Skill Books. Tutors were asked to include information on what Skill Book their students were now using. Of the thirty-nine students in our sample presently being tutored, almost one-third, 30.8 percent, were in Skill Book 2. Eighteen percent were using Skill Book 1. Skill Books 3 and 4 each 20.5 percent of the students using them. The Advanced Skill Books 5 and 6 only accounted for 5.1 percent each of the total.

Past Student Progress Ihrough Skill Books. There were 42 tutor responses on 99 students to the question, "Please estimate ho: many of your past students have progressed to the following Skill Books." The overall picture of student progress indicated that while only 2 percent of the students reached Skill Book 6, 15.2 percent progressed to Skill Book 5. Skill Books 2, 3, and 4 all had similar percentages of students progressing to them, 23.2, 26.3, and 23.2 percent respectively. Ten students, 10.1 percent had not progressed beyond Skill Book 1 .

Student Dropouts. We asked the tutors to estimate how many of their students had dropped out, and for what reasons. Wie had no data on those students, so we were unable to compare them with the NALA sample in terms of "Persisters and Dropouts." Out of the 41 tutor responses, there was data on 
62 student dropouts. The largest percentage, 24.2, had moved away. Those not learning, progressing too slowly, or with family problems each comprised 11.3 percent of the total. Students who lost interest, had personal problems or had been sent to the penitentiary each accounted for 6.5 percent. Illness and other problems accounted for 7.9 percent.

Only 14.5 percent, those who had progressed to a high school class ( 6.5 percent) or got a job ( 8 percent), left for a positive reason.

\section{Summary of Student Characteristics}

Male and female students were about evenly divided in both samples and the mean age in both was slightly over 35 years. White students comprised the largest category in both samples, black students the second largest. Over onethird of both groups heard about the literacy program through a friend or relative. Most of the students were married in both samples. 'Tutors' and students' homes were the main places tutors and students met. Most students in NALA's sample attended one class per week, whereas in Multnomah County's sample those who met once a week and those who met twice a week were almost evenly divided. 
CHAPTER VI

\author{
PUBLICITY AND TRAINING
}

There were two areas of information that were not included in The NALA Study that we wanted to explore, publicity and training.

\title{
Publicity
}

In order for a program to succeed, especially a program which relies on volunteer help, there must be adequate publicity. If the people who are interested in volunteering are not reached, the program must rely on those already involved.

We wanted to find out how the volunteers first heard about the literacy program and we wanted their suggestions for improving the publicity to both potential students and tutors. The questions were not meant to be a criticism of the existing publicity, rather we hoped that there might be some interesting suggestions which could be incorporated into the existing program.

\section{How Tutors And Students First Heard of Volunteer}

Literacy. The majority of tutors and students first heard about the literacy program through some type of personal contact, being informed by a friend or relative, hearing about it at church or through another literacy group. The remainder heard about the program through the mass media, 
newspapers and television. Church, college and other bulletins and newsletters were suggested as likely places for an ad for tutors. One person suggested using placemats in restaurants to advertise for tutors.

Use Of The Media. Several questions were asked in order to ascertain whether there were any consistent pattern to the radio, television and newspaper habits of the tutors, the idea being that those would be good spots to advertise for tutors. The results were inconclusive. It can only be stated that the tutors have varied tastes and interests. The results are nonetheless interesting.

There vere seventy-four replies to the question "What radio station do you most often listen to?" Nine replied that the listen to station KUPL, eight to station KINK. The other replies were scattered over nineteen stations. Many people listed several newspapers that they read regularly, the two most popular being the daily Oregonian (62) and the daily Journal (23). There was no consistent viewing pattern for the television stations. Twenty-five watch KGW, Channel 8 (NBC), sixteen watch KOIN, Channel 6 (CBS), and fourteen :atch KATU, Channel 2( $\mathrm{ABC})$. Another twelve watch all three network news shows at various times. Three persons replied that they do not watch the news, either because it is too depressing or because it is too violent.

Program Publicized Enough. When asked if the program was publicized enough to attract volunteer tutors, seven 
said it was, thirty-eight said it was not and forty-seven were not sure.

Four tutors felt the program was publicized enough to attract students, twenty-nine thought it was not and fiftythree were not sure.

Sugfestions For Attracting Tutors. There were many recommendations for attracting volunteer tutors. In addition to the ads placed in various newspapers, it was sugEested that nemspaper feature stories be done, especially those emphasizing a "success story" approach. Many places were suggested as prime targets for either posters, flyers, or guest speakers: schools and PTA organizations, Retired Teachers Associations, grocery stores, restaurants, fairs, and Senior Citizens groups.

\section{Summary of Publicity}

Although most of the comments about publicity were within the scope we expected they did serve to emphasize the wide range of media available to reach potential students and tutors. John Stauffer, in The NALA Study suggested door to-door canvassing and involvement of neighborhood organizations in the student recruitment program. This person-toperson approach seems the most effective since the majority of students do hear about the program from someone involved in the program as either a student or tutor. 
Irainine:

Once a person has been attracted to the literacy program, he or she must be trained to tutor. The training workshops are held about every other month in Multnomah County and usually two workshops are conducted back-to-back on the same weekend.

Enough Training To Tutor Adequately. We asked the tutors if they felt they had enough training to tutor adequately. Seventy-six percent, 70 tutors, felt they did. Six tutors, 6.5 percent, felt it was not adequate and 15.2 percent, fourteen tutors, were not sure. Part of this latter Eroup included volunteers who have not been assigned students and therefore found it hard to know if the training they had received was adequate. One tutor wrote:

We had enough training to learn how to start out, but I think adequacy comes only with practice-and even then it depends on the rapport between the student and tutor. I really can't answer the question. My student and I, for various reasons, have had a very on again, off again relationship. Right no:: it is off, and she has moved far enough away that I'm not sure I want it on again.

Training In Specific Areas. We asked if the tutors would like more training in specific areas. Figure 1 on the next page, shows the results of this question.

The responses to the need for a refresher workshop and individual help with tutoring problems were almost evenly divided between the three responses, yes, no, and not sure, and give no clear indication of the desire for this type of 
YES

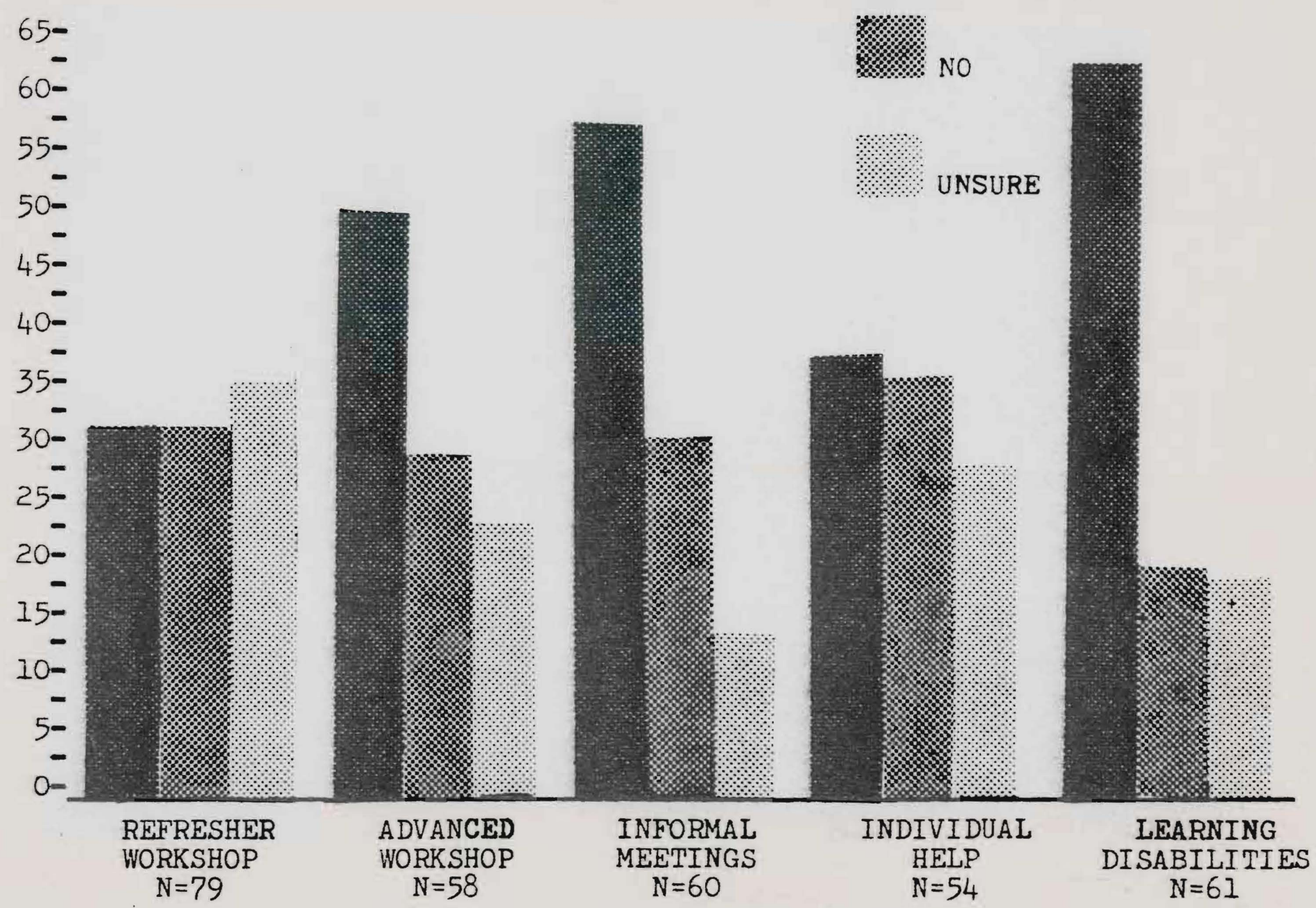

Figure 1. Volunteer interest in further training opportunities. 
training. One tutor suggested a one-day quickie refresher \#orkshop to be available once a month.

A significant number of tutors indicated that they :ould be interested in meeting informally ith other tutors. Approximately 57 percent of those responding said they would like to meet with other tutors, and 13 percent were not sure. Thirty percent indicated that they would not like informal meetings.

The need for an advanced workshop concentrating on the more advanced Skill Books was expressed by approximately 48 percent of the 58 tutors responding. Twenty-nine percent said no, and twenty-two percent were unsure. One tutor suggested that advanced training emphasize structured content and that sessions be given especially for expanding problem sections of a lesson.

In the area of learning disabilities a significant number of tutors expressed a desire for more help. Of the 61 tutors responding to this question, 62 percent said they yould like more training. Eighteen percent were not sure and 19.7 percent said they would not like training in learning disabilities. One respondent commented that she and her student wasted several weeks because she did not recognize a learning disability. Several people commented on the need for more help in recognizing dyslexia.

Tutor Suggestions For Training. One tutor felt that more time in class to practice would be helpful. She suggested working in small groups or two persons working 
together. Another tutor praised the program adding that all of the training suggestions were "possible for the asking whenever I feel the need." Another stated, "I feel the techniques taught are good--they offer enough structure vithout imposing on the individual student." One respondent suggested distributing a basic reading list for tutors and a list of available adult education courses to supplement training to recognize learning disabilities. Another interesting suggestion was to use tape recorded sessions at different Skill Book levels to train tutors. The use of tapes or cassette recordings could supplement the training received in the workshops. Teaching cursive writing was another area in which several tutors requested help. Using Training In Other Ways. We asked the tutors if they were using their training in any other way than tutoring one-to-one. Several people responded that they use their trainine to teach in a group, particularly Teaching English as a Second Language. Three tutors are using the Laubach method to teach their o:m children, and three are using their training in their professional teaching careers. Another tutor is using the training to tutor low level readers at Mt. Hood Community College. Two persons are adapting the method to tutor retarded adults at Goodwill Industries. Another volunteer is using the training to write materials for new readers rather than tutoring. 


\section{CHAPTER VII}

\section{RECOMMENDATIONS}

There were some interesting comments under the questions "What could the Laubach program do to make tutoring easier for you?" and "Please comment on any changes you vould like to see made," some of which are included elsewhere in this report. On the whole they were very favorable toward the program: "It's just fine." "It is great and I wouldn't change it." "They make it very easy." "Can't think of anything not already being done." "The program is excellent." "I have a student with a deep interest who confides in me and I believe we are going to be a winning team!" "I am new at tutoring and am always impressed with the wonderful tutors I meet at Laubach."

There are some obvious difficulties which make it hard to carry out many of the excellent suggestions by the tutors. Time, money and volunteer staff are three.

Some tutors expressed the need for convenient meeting places outside the tutor's and student's home. One tutor suggested a full time downtown language lab. It would be a tremendous help to have a tutoring center where students and tutors could meet. Babysitting facilities at the center would enable both students and tutors to participate despite the fact that they had small children. The babysitting 
service could contain reading readiness materials and games for the children. At such a center supplementary materials of all types could be available--magazines, driving instructions, tape cassettes, videotapes--if money were no object and if there vere volunteers who had the time to staff the center. If the New Readers Bookstore were also housed in such a center the tutors and students could become more aware of available materials.

What can be done now to enhance the program? Some of the suggestions by the tutors were within the realm of immediate possibility. Some may be available now. This bring us to the area of communication. What contact do the volunteers have with office staff and with one another? There is a monthly newsletter which is sent to all tutors in order to keep them abreast of what is going on. The tutor who expressed a desire for someone to call now and then "just to see how I'm doing" is most likely expressing a feeling shared by many tutors. It would entail some effort to contact each tutor monthly or bi-monthly. Perhaps it would be a good position for someone who wants to help, but finds that tutoring is not where his or her talents lie. Such a person could keep track of whether the tutor is ready for another student, is having special problems, or is not tutoring at the moment. Such a friendly call, with the implication that help is available if needed, might be just the morale boost some tutors need. The volunteer caller 
should have a kno:Iledge of extra resource material which might be available to the students and tutors.

Some tutors expressed a desire for extra resource materials, such as signs to use in driver training, nonsense stories and poems, more teaching aids, more outside readings and guides to help become more knowledgeable about the sources already available, eg., standard magazines and books found in homes and libraries. Another said, "In both cases with my two students it seemed to me these young men, who were by no means 'dumb' and were making their way in the world without reading, felt that the lesson books were too babyish."

One person felt that an initial interview by the person assigning students, with both the student and the tutor, would help determine whether the two of them would be a compatible team. Such an interview could be helpful in working out problems with meeting places, times and expectations of both parties.

There were a few comments from disenchanted tutors who were unhappy with their relationship with the student. More frequent contact with the program personnel could help resolve some of these problems. The student could be placed with another tutor to prevent either the student or the tutor from dropping out of the program. Or, the intervention of a staff person might prove beneficial in mutually resolving the problem.

Tutors were asked whether their student ever needed help not related to reading and whether they were able to 
refer them to other resources. Tutor response on the question about resources included wanting information of Welfare, medical and dental care, counseling, employment, food stamps, housing, immigration, home repair and upkeep, legal assistance, and math and grammar tutoring. Some small resource booklet might be prepared in the printing shop located at the main office. There are a number of resource booklets, such as "Where To Turn" published by the Tri-County Community Council, which could be used. However, the problems of the students being tutored are unique enough to warrant the publication of a special guide to resources. At the end of each training workshop the tutors might be given one or charged a nominal fee to cover the cost of printing.

Only a small number of tutors felt the program was publicized enough to attract students and tutors. The rest felt it was not or they were not sure. There are many ways to reach potential students and tutors, some of which cost nothing: public service announcements on the radio, human interest stories in the newspapers, and of course, word of mouth, students and tutors passing the good word. Over onethird of the students in The NALA Study and in our sample first heard about the program from a friend or relative. Along this line, the word, and possibly a brochure about the program could be given to public agencies who might come in contact with potential students.

There is an emphasis on valuing one's ethnic heritage and this emphasis should be recognized and utilized when 
trying to reach potential tutors and students. Individualized brochures designed to appeal to certain groups of people could be prepared. Brochures written and illustrated by foreign students in their native language could be used to promote the English as a Second Language program. Brochures desifned by local black artists could recognize the uniqueness of the black culture while attracting both students and tutors. Similar brochures could be prepared to reflect a recosnition of the Spanish-American, American Indian and other cultural groups. Ideas for such brochures could be Eenerated through student involvement.

Several people were unhappy about the long wait before their first student was assigned or before another student was assigned after one had terminated. If the time lag is too great the volunteer may lose interest and motivation, assume other responsibilities and be "too busy" when called on to tutor.

The assignment of students depends upon the availability of requests for tutoring. The Multnomah County program currently relies upon a "self-referral" system of student recruitment. A student must take the initiative to call the program office to request tutoring. This insures that the individual is motivated. However, this may act as a barrier to some potential students who have little information about the program. Active student recruitment to provide information and contact with the program could increase the number 
of students being served and provide continuous tutoring opportunities for the volunteers.

The tutor suggestions for training are included in Chapter VI. The majority of the tutors felt they had received adequate training to begin tutoring. Most of the requests were for supplemental help, such as more training in "orking with learning disabilities, and help with the advanced skill books. Several tutors recommended the use of tape cassette recordings to supplement the workshop training. This could be an interesting area of experimentation. Workshop sessions could be taped and given to new tutors to use and an assessment could be made of the usefulness of this technique.

Over half of the tutors requested informal meetings with other tutors. Such meetings could provide a forum for discussion of problems and training needs. It could also serve the purpose of enhancing communication between the volunteers and staff.

Almost all the suggestions for improving or enhancing the literacy program lie within the area of communication. Sometimes the obvious aspects of a program tend to get ignored. We feel more contact between volunteers and staff would serve to make the program more cohesive and more effective. People need feedback, praise, encouragement. They need to feel involved in the greater whole. The tutoring experience is fulfilling in itself, but open lines of 
communication would involve the tutors in a way which might keep them active and enthusiastic for many years. 


\section{BIBLIOGRAPHY}

Barron, W. E., et al. Adult Functional Competency: A Summary. University of Texas, Austin: Division of Extension, March, 1975.

Ginzberg, Eli, and Bray, Douglas W. The Uneducated. New York: Columbia University Press, 1953.

Jeffries, Sir Charles. Illiteracy: A World Problem. New York: Praeger Publishers, 1967.

Lanning, Frank W., and Many, Wesley A., Eds. Basic Education for the Disadvantaged Adult: Theory and Practice. Boston: Houghton Mifflin Co., 1966.

Laubach, Frank C., Kirk, Elizabeth M., and Laubach, Robert S. Everyday Reading and Writing. Syracuse, New York: New Readers press, 1970.

Laubach, Frank C. Forty Years with the Silent Billion.

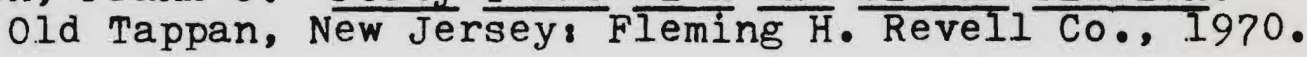

Laubach, Frank C., Kirk, Elizabeth M., and Laubach, Robert S. The New Streamlined English Series. Syracuse, New York: New Readers Press, 1973.

Laubach, Frank C., and Laubach, Robert S. Toward World Literacy: The Each one Teach One Way. New York: Syracuse university Press, 1961.

Medary, Marjorie. Each One Teach One: Frank Laubach, Friend to Mililions. New Yorks Longmans, Green and Co., I954.

Smith, Carl B., and Fay, Leo C. Getting People to Read: Volunteer Programs that Work. New York Delacorte Press, 1973.

Smith, Edwin H. Literacy Education for Adolescents and Adults. San Francisco, California, Boyd and Fraser Co., 1970.

Stauffer, John M. The NALA Study A Description of the National Affiliation for Literacy Advance. Syracuse, New York 8 New Readers Press, 1973. 
U.S., Bureau of the Census. Characteristics of the Population: Oregon. Social and Economic Statistics Administration, Vol. I, Part 39, January, 1973.

U.S., Bureau of the Census. Educational Attainment, March 1971. Current Population Reports, Series P-20, No. 229, December, 1971.

U.S., Bureau of the Census. General Social and Economic Characteristics 1970 Census of Population: Oregon. Series PC(1)-C $39, \mathrm{Feb}, 1972$. 
APPENDIX 
TABLE IV

SELECTED TUTOR CHARACTERISTICS

\begin{tabular}{lrrrr}
\hline & No. & \multicolumn{3}{c}{$\begin{array}{c}\text { Multnomah Co. } \\
\text { No. }\end{array}$} \\
\hline Sex & & & & \\
Male & 45 & 8.8 & 16 & 17.4 \\
Female & 464 & 91.2 & 76 & 82.6 \\
Age & & & & \\
16-20 & 5 & 1.0 & 2 & 2.1 \\
21-30 & 35 & 6.9 & 23 & 25.3 \\
31-40 & 58 & 11.4 & 13 & 14.3 \\
$41-50$ & 135 & 26.5 & 8 & 8.8 \\
$51-60$ & 143 & 28.0 & 11 & 12.1 \\
$61-70$ & 41 & 8.1 & 20 & 22.0 \\
$71-80$ & 41 & 8.1 & 13 & 14.2 \\
$81-90$ & 1 & .2 & 1 & 1.1 \\
No data & 0 & 0.0 & 1 & 1.1
\end{tabular}

Ethnic Group

White

$502 \quad 98.6$

82

96.5

Black

1.2

1.2

American Indian

.2

0.0

Oriental

0.0

2.3

Place of Birth

United State

Mexico

487

2

Canada

10

95.6

85

93.4

.4

0.0

Europe

2.0

1.1

1.8

Asia

9

.2

$3 \quad 3.3$

1

1

$2 \quad 2.2$ 
TABLE IV Continued

\section{Marital Status}

Married
Divorced
Separated
Uidowed
Single
No data

383

75.3

50

$54 \cdot 4$

20

3.9

6

6.5

1.2

1

1.1

$52 \quad 10.2$

10

10.9

52

10.2

1

24

26.0

1

1.1

Children Living at Home

$\begin{array}{lrrrr}\text { None } & 279 & 54.8 & 67 & 72.8 \\ \text { One } & 96 & 18.9 & 8 & 8.7 \\ \text { Two } & 65 & 12.8 & 12 & 13.0 \\ \text { Three } & 44 & 8.6 & 3 & 3.3 \\ \text { Four } & 20 & 3.9 & 1 & 1.1 \\ \text { Five-Eight } & 5 & 1.0 & 1 & 1.1\end{array}$

Job Record

$\begin{array}{lrrrr}\text { Held Job } & 475 & 93.3 & 85 & 92.4 \\ \text { Never Held Job } & 33 & 6.5 & 6 & 6.5 \\ \text { No Data } & 1 & .2 & 1 & 1.1\end{array}$

Employment Status

$\begin{array}{lrrrr}\text { Full Time } & 108 & 21.2 & 32 & 34.8 \\ \text { Part Time } & 82 & 16.1 & 15 & 16.3 \\ \text { Looking for } & & & & \\ \quad \text { Work } & 9 & 1.8 & 4 & 4.3 \\ \text { House rife } & 205 & 40.2 & 9 & 9.8 \\ \text { Retired } & 99 & 19.5 & 29 & 31.5 \\ \text { Full Time } & & 1.2 & 3 & 3.3 . \\ \quad \text { Student } & 6 & & & \end{array}$


TABLE IV Continued

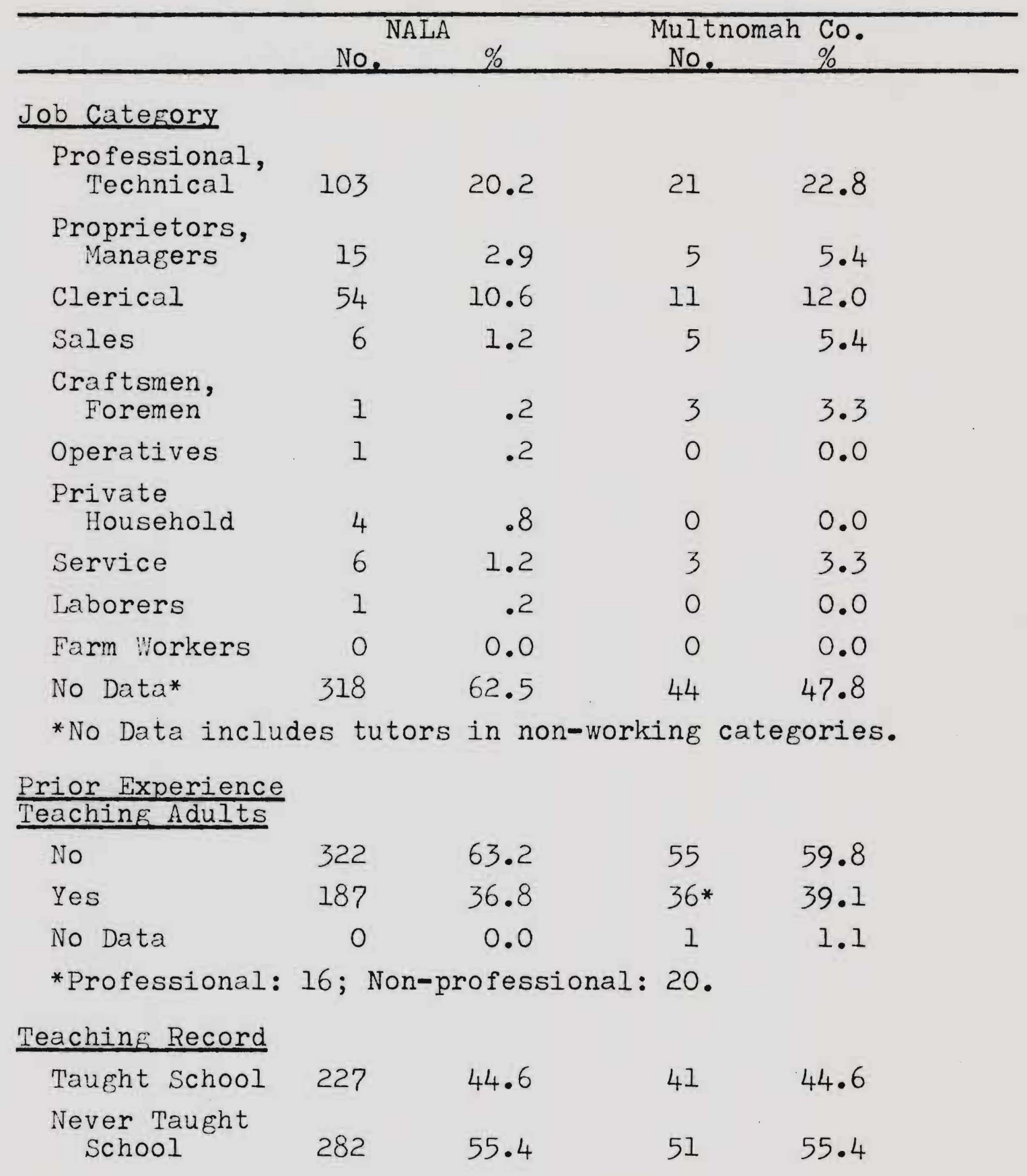


TABLE IV Continued

\begin{tabular}{|c|c|c|c|c|}
\hline & \multicolumn{2}{|c|}{ NALA } & \multicolumn{2}{|c|}{$\begin{array}{l}\text { Multnomah Co. } \\
\text { No. } \quad \%\end{array}$} \\
\hline \multicolumn{5}{|c|}{$\begin{array}{l}\text { Type of Current } \\
\text { Professional Teaching }\end{array}$} \\
\hline None & 432 & 84.8 & 70 & 76.0 \\
\hline Elementary & 35 & 6.9 & 7 & 7.6 \\
\hline Special Ed. & 1 & .2 & 2 & 2.2 \\
\hline Secondary & 17 & 3.3 & 2 & 2.2 \\
\hline College & 6 & 1.2 & 1 & 1.1 \\
\hline $\mathrm{ABE}$ & 3 & .6 & 5 & 5.4 \\
\hline ESI & 3 & .6 & 2 & 2.2 \\
\hline $\begin{array}{l}\text { Paid Private } \\
\text { Tutor }\end{array}$ & 8 & 1.6 & 0 & 0.0 \\
\hline $\begin{array}{l}\text { On-the-Job } \\
\text { Instructor }\end{array}$ & 4 & .8 & 1 & 1.1 \\
\hline $\begin{array}{l}\text { Early Childhood } \\
\text { Education }\end{array}$ & 0 & 0.0 & 1 & 1.1 \\
\hline Childbirth Ed. & 0 & 0.0 & 1 & 1.1 \\
\hline \multicolumn{5}{|l|}{ Personal Income } \\
\hline$\$ 1,000-2,999$ & 49 & 9.6 & 7 & 7.6 \\
\hline$\$ 3,000-4,999$ & 20 & 3.9 & 9 & 9.8 \\
\hline$\$ 5,000-6,999$ & 32 & 6.3 & 14 & 15.2 \\
\hline$\$ 7,000-8,999$ & 21 & 4.1 & 7 & 7.6 \\
\hline$\$ 9,000-10,999$ & 24 & 4.7 & 7 & 7.6 \\
\hline$\$ 11,000-15,999$ & 30 & 5.9 & 11 & 12.0 \\
\hline$\$ 16,000-20,999$ & 8 & 1.6 & 2 & 2.1 \\
\hline $\begin{array}{l}\text { More than } \\
\$ 20,000\end{array}$ & 6 & 1.2 & 1 & 1.1 \\
\hline No Data* & 319 & 62.7 & 34 & 37.0 \\
\hline
\end{tabular}


TABLE IV Continued

\begin{tabular}{lrrrr}
\hline & No. & $\%$ & \multicolumn{2}{c}{ Multnomah Co. } \\
No. & $\%$ \\
\hline Family Income & & & & \\
\hline$\$ 1,000-2,999$ & 7 & 1.4 & 1 & 1.1 \\
$\$ 3,000-4,999$ & 18 & 3.5 & 5 & 5.4 \\
$\$ 5,000-6,999$ & 38 & 7.5 & 16 & 17.4 \\
$\$ 7,000-8,999$ & 33 & 6.5 & 7 & 7.6 \\
$\$ 9,000-10,999$ & 64 & 12.6 & 11 & 12.0 \\
$\$ 11,000-15,999$ & 115 & 22.5 & 23 & 25.0 \\
$\$ 16,000-20,999$ & 64 & 12.6 & 9 & 9.8 \\
More than & & & & \\
$\$ 20,000$ & 70 & 13.8 & 8 & 8.7 \\
No Data & 100 & 19.6 & 12 & 13.0
\end{tabular}

Grades Completed

$\begin{array}{lrrrr}\text { Eight } & 2 & .4 & 0 & 0.0 \\ \text { Nine } & 3 & .6 & 0 & 0.0 \\ \text { Ten } & 2 & .4 & 1 & 1.1 \\ \text { Eleven } & 12 & 2.4 & 2 & 2.2 \\ \text { T'velve } & 489 & 96.0 & 84 & 91.3 \\ \text { No Data } & 1 & .2 & 5 & 5.4\end{array}$

College Education

$\begin{array}{lrrrr}\text { No College } & 113 & 22.2 & 28 & 30.5 \\ \text { Some College } & 126 & 24.8 & 21 & 22.8 \\ \text { College Grad. } & 269 & 52.8 & 38 & 41.3 \\ \text { No Data } & 1 & .2 & 5 & 5.4\end{array}$

Craduate Degree

$\begin{array}{lrrrr}\text { None } & 433 & 85.0 & 68 & 73.9 \\ \text { Seminary } & 5 & 1.0 & 1 & 1.1 \\ \text { Master's } & 66 & 13.0 & 18 & 19.6 \\ \text { Ph.D. } & 4 & .8 & 0 & 0.0 \\ \text { No Data } & 1 & .2 & 5 & 5.4\end{array}$


TABLE IV Continued

\begin{tabular}{|c|c|c|c|c|}
\hline \multirow{2}{*}{$\begin{array}{l}\text { How First Heard of } \\
\text { Volunteer Literacy }\end{array}$} & \multicolumn{2}{|c|}{ NALA } & \multicolumn{2}{|c|}{$\begin{array}{l}\text { Multnomah Co. } \\
\text { No. }\end{array}$} \\
\hline & \\
\hline \multicolumn{5}{|l|}{ Church } \\
\hline Friend/Relative & 49 & 9.6 & 27 & 29.3 \\
\hline Literacy Organ. & 70 & 13.8 & 5 & 5.4 \\
\hline \multicolumn{5}{|l|}{ Through Frank } \\
\hline Newspaper & 117 & 23.0 & 22 & 23.9 \\
\hline Television & 13 & 2.6 & 3 & 3.3 \\
\hline Radio & 8 & 1.6 & 3 & 3.3 \\
\hline Magazine & 6 & 1.2 & 1 & 1.1 \\
\hline Other & 27 & 5.3 & 10 & 10.9 \\
\hline No Data & 2 & .4 & 3 & 3.3 \\
\hline \multicolumn{5}{|l|}{$\begin{array}{l}\text { Reasons Tutors Want } \\
\text { to Teach }\end{array}$} \\
\hline To Help Others & 282 & 55.3 & 46 & 50.0 \\
\hline Self-fulfillment & 87 & 17.1 & 10 & 10.9 \\
\hline $\begin{array}{l}\text { Religiously } \\
\text { Motivated }\end{array}$ & 50 & 9.8 & 0 & 0.0 \\
\hline $\begin{array}{l}\text { Enjoyment of } \\
\text { Teaching }\end{array}$ & 64 & 12.6 & 10 & 10.9 \\
\hline $\begin{array}{c}\text { Importance of } \\
\text { Reading }\end{array}$ & 0 & 0.0 & 11 & 11.9 \\
\hline Sa: Need & 0 & 0.0 & 5 & 5.4 \\
\hline Other Reasons & 13 & 2.6 & 7 & 7.6 \\
\hline No Data & 13 & 2.6 & 3 & 3.3 \\
\hline
\end{tabular}


TABLE IV Continued

\begin{tabular}{lrrrr}
\hline & NALA & $\begin{array}{c}\text { Multnomah } \\
\text { No. }\end{array}$ & $\begin{array}{l}\text { Co. } \\
\%\end{array}$ \\
\hline Current Number of & & & & \\
Students Per Tutor & & & & \\
\cline { 2 - 2 } None & 0 & 0.0 & 25 & 34.7 \\
One & 360 & 70.6 & 32 & 44.4 \\
Two & 82 & 16.1 & 5 & 6.9 \\
Three & 25 & 4.9 & 2 & 2.8 \\
Four & 13 & 2.6 & 0 & 0.0 \\
Five & 9 & 1.8 & 0 & 0.0 \\
More than Five & 20 & 4.0 & 3 & 4.2 \\
No Data & 0 & 0.0 & 5 & 7.0
\end{tabular}

Students Taught in Last Year Per Tutor

$\begin{array}{lrrrr}\text { Zero } & 0 & 0.0 & 17 & 23.6 \\ \text { One } & 223 & 43.7 & 32 & 44.4 \\ \text { Two } & 102 & 20.0 & 13 & 18.0 \\ \text { Three } & 64 & 12.6 & 1 & 1.4 \\ \text { Four } & 29 & 5.7 & 1 & 1.4 \\ \text { Five } & 30 & 5.9 & 2 & 2.8 \\ \text { Six-Ten } & 38 & 7.5 & 1 & 1.4 \\ \text { More than Ten } & 21 & 4.2 & 2 & 2.8 \\ \text { No Data } & 2 & .4 & 3 & 4.2\end{array}$

Time as Tutor

$\begin{array}{lrrrr}\text { Less than 6 mo. } & 68 & 13.4 & 25 & 34.8 \\ 6 \text { mo. to I yr. } & 273 & 53.6 & 18 & 25.0 \\ 2 \text { yr. } & 84 & 16.5 & 8 & 11.1 \\ 3 \text { yr. } & 43 & 8.4 & 3 & 4.2 \\ 4 \text { yr. } & 20 & 3.9 & 2 & 2.8 \\ 5 \text { yr. } & 4 & .8 & 6 & 8.3 \\ 6-10 \text { yr. } & 13 & 2.6 & 7 & 9.6 \\ \text { l1-15 yr. } & 2 & .4 & 0 & 0.0 \\ \text { No Data } & 2 & .4 & 3 & 4.2\end{array}$


TABLE IV Continued

\begin{tabular}{lrrrr}
\hline & NALA & \multicolumn{2}{c}{$\begin{array}{c}\text { Multnomah Co. } \\
\text { No. }\end{array}$} \\
\cline { 1 - 1 } $\begin{array}{l}\text { Tutors Career Total } \\
\text { of Students }\end{array}$ & & & & \\
\cline { 1 - 2 } One & 176 & 34.6 & 39 & 54.2 \\
Two & 99 & 19.4 & 9 & 12.5 \\
Three & 62 & 12.2 & 6 & 8.3 \\
Four & 25 & 4.9 & 2 & 2.8 \\
Five & 34 & 6.7 & 3 & 4.2 \\
Six-Ten & 59 & 11.6 & 7 & 9.6 \\
Eleven-Fifteen & 21 & 4.1 & 1 & 1.4 \\
Sixteen-Twenty & 9 & 1.8 & 1 & 1.4 \\
More than Twenty & 20 & 3.9 & 1 & 1.4 \\
No Data & 4 & .8 & 3 & 4.2
\end{tabular}


A COMPARISON OF SELECTED CHARACTERISTICS BETWEEN

MULTNOMAH COUNTY VOLUNTEERS WHO ARE

TUTORING NOW, NOT TUTORING NOW, AND WHO HAVE NEVER TUTORED

\begin{tabular}{lrrr} 
Characteristics & Tutoring & Not Tutoring & Never Tut \\
\cline { 2 - 4 } Sex & $N=46$ & & $N=26$ \\
Fernale & 39 & 21 & 14 \\
Male & 7 & 5 & 3 \\
Age & & & \\
\hline $16-20$ & 0 & 1 & 1 \\
$21-30$ & 9 & 9 & 6 \\
$31-40$ & 3 & 3 & 4 \\
$41-50$ & 4 & 1 & 2 \\
$51-60$ & 6 & 3 & 2 \\
$61-70$ & 12 & 5 & 2 \\
$71-80$ & 10 & 4 & 0 \\
$81-90$ & 1 & 0 & 0 \\
No Data & 1 & 0 & $19-67$ \\
Range & $24-83$ & $17-76$ & 37.2 \\
Mean & 55.4 & 46.6 &
\end{tabular}

Marital Status

$\begin{array}{lrrr}\text { Married } & 24 & 16 & 7 \\ \text { Divorced } & 4 & 1 & 1 \\ \text { Separated } & 0 & 1 & 0 \\ \text { Widowed } & 8 & 2 & 1 \\ \text { Single } & 9 & 6 & 8 \\ \text { No Data } & 1 & 0 & 0\end{array}$

Teaching Record

Taught 20

$12 \quad 8$

Never Taught

26

14

9 
TABLE V Continued

Characteristics Tutoring Not Tutoring Never Tutored

Employment status

$\begin{array}{lrlr}\text { Full Time } & 16 & 6 & 10 \\ \text { Part Time } & 3 & 9 & 1 \\ \text { Looking for Work } & 0 & 1 & 2 \\ \text { Houserife } & 3 & 4 & 2 \\ \text { Retired } & 22 & 6 & 1 \\ \text { Student } & 2 & 0 & 1\end{array}$

Number of Children Living at Home

$\begin{array}{lrrr}\text { None } & 38 & 18 & 13 \\ \text { One } & 3 & 2 & 1 \\ \text { Two } & 3 & 4 & 3 \\ \text { Three } & 1 & 1 & 0 \\ \text { Four } & 1 & 0 & 0 \\ \text { Five or More } & 0 & 1 & 0\end{array}$


TABLE VI

SELECTED STUDENT CHARACTERISTICS

\begin{tabular}{lrrrr}
\hline & NALA & \multicolumn{3}{c}{ Multnomah Co. } \\
\hline Nex & $\%$ & $\%$ \\
\hline Male & & & & \\
Female & 259 & 50.9 & 19 & 48.7 \\
Ase & 250 & 49.1 & 20 & 51.3 \\
16-20 & & & & \\
21-30 & 32 & 6.3 & 1 & 2.6 \\
31-40 & 168 & 33.0 & 17 & 43.6 \\
41-50 & 163 & 32.0 & 10 & 25.6 \\
51-60 & 80 & 15.7 & 4 & 10.3 \\
61-70 & 36 & 7.1 & 2 & 5.1 \\
71-80 & 26 & 5.1 & 1 & 2.6 \\
No Data & 4 & .8 & 2 & 5.1 \\
Ethnic Group & 0 & 0.0 & 2 & 5.1 \\
White & & & & \\
Spanish American & 128 & 25.1 & 1 & 2.6 \\
Black & 120 & 23.6 & 8 & 20.5 \\
Oriental & 32 & 6.3 & 2 & 5.1 \\
Marital Status & & & & \\
Single & 109 & 21.4 & 15 & 38.5 \\
Married & 316 & 62.1 & 17 & 43.6 \\
Separated & 29 & 5.7 & 0 & 0.0 \\
Divorced & 29 & 5.7 & 3 & 7.7 \\
Widowed & 25 & 4.9 & 2 & 5.1 \\
No Data & 1 & .2 & 2 & 5.1 \\
& & & &
\end{tabular}


TABLE VI Continued

\begin{tabular}{|c|c|c|c|c|}
\hline \multirow{2}{*}{$\begin{array}{l} \\
\text { Ho: Students Heard } \\
\text { of Classes }\end{array}$} & \multicolumn{2}{|c|}{ No. ${ }^{\text {NALA }} \%$} & \multicolumn{2}{|c|}{$\begin{array}{l}\text { Multnomah Co. } \\
\text { No. } \% \\
\end{array}$} \\
\hline & & & & \\
\hline Public School & 27 & 5.3 & 0 & 0.0 \\
\hline Fmployer & 46 & 9.0 & 5 & 12.8 \\
\hline Church & 25 & 4.9 & 0 & 0.0 \\
\hline Welfare Agency & 33 & 6.5 & 3 & 7.7 \\
\hline Friend/Relative & 202 & 39.7 & 14 & 35.9 \\
\hline Newspaper & 47 & 9.2 & 3 & 7.7 \\
\hline Television & 34 & 6.7 & 3 & 7.7 \\
\hline Radio & 39 & 7.7 & 1 & 2.6 \\
\hline Magazine & 2 & .4 & 0 & 0.0 \\
\hline Other & 45 & 8.8 & 2 & 5.1 \\
\hline No Data & 9 & 1.8 & 8 & 20.5 \\
\hline \multicolumn{5}{|l|}{ Teaching Location } \\
\hline Tutor's Home & 130 & 25.5 & 10 & 25.6 \\
\hline Student's Home & 152 & 29.9 & 11 & 28.2 \\
\hline $\begin{array}{l}\text { Student's Place } \\
\text { of "Vork }\end{array}$ & 17 & 3.3 & 7 & 17.9 \\
\hline Church Facility & 122 & 24.0 & 4 & 10.3 \\
\hline $\begin{array}{l}\text { Community Service } \\
\text { Facility }\end{array}$ & 27 & 5.3 & 2 & 5.1 \\
\hline Public School & 25 & $4 \cdot 9$ & 1 & 2.6 \\
\hline $\begin{array}{c}\text { Other Public } \\
\text { Facility }\end{array}$ & 23 & $4 \cdot 5$ & 3 & 7.7 \\
\hline All others & 12 & 2.4 & 1 & 2.6 \\
\hline No Data & 1 & .2 & 0 & 0.0 \\
\hline
\end{tabular}




\section{TABLE VI Continued}

\begin{tabular}{lrrrr}
\hline & \multicolumn{2}{c}{ NALA } & \multicolumn{2}{c}{$\begin{array}{c}\text { Multnomah Co. } \\
\text { No. }\end{array}$} \\
\hline Number of Classes & \multicolumn{1}{c}{$\%$} & \\
\hline Per Week & & & & \\
\hline Less than One & 4 & .8 & 1 & 2.6 \\
One & 282 & 55.4 & 16 & 41.0 \\
T:: & 185 & 36.3 & 17 & 43.6 \\
Three & 10 & 2.0 & 5 & 12.8 \\
Four-Five & 6 & 1.2 & 0 & 0.0 \\
No Data & 22 & 4.3 & 0 & 0.0
\end{tabular}


TABLE VII

STUDENT PROGRESS AND REASONS FOR DROPPING OUT AS REPORTED BY

MULTNOMAH COUNTY TUTORS

Skill Book Progress on Students Now Being Tutored $\mathrm{N}=39$ Skill Book Number

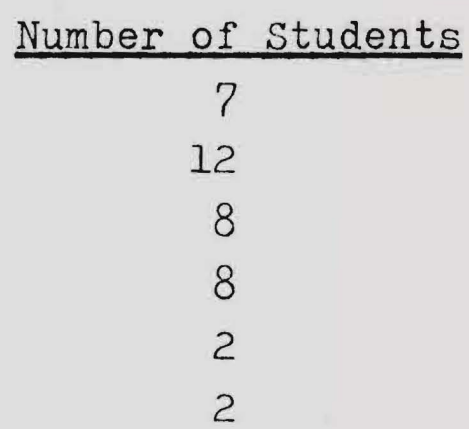
$\%$
18.0
30.8
20.5
20.5
5.1
5.1 1

2

3

4

5

6*

2

* Everyday Reading and Writing

Skil1 Book Progress on Past Students $N=99$

Skill Book Number

\begin{tabular}{c} 
Number of Students \\
\hline 10 \\
23 \\
26 \\
23 \\
15 \\
2
\end{tabular}

$$
\begin{gathered}
\% \\
10.0 \\
23.2 \\
26.3 \\
23.2 \\
15.2 \\
2.0
\end{gathered}
$$

Student Dropouts $N=62$

Reasons for Dropping out

Number of Students

$\%$

Not Learning

Lost Interest

Progress too Slo:"

$?$

11.3

6.5

Family Problems

4

11.3

Sent to Penitentiary

7

11.3

4

6.5

Personal Problems

4

6.5

Illness

2

3.2

Moved Away

15

Got a Job

24.2

8.0

Progressed to High School Reading Class 
Dear Tutors:

We are in the process of studying the Oregon Literacy Program. The purpose of this study is to compare the characteristics of Multnomah County tutors with a national profile, and to gather information on what you feel could be done to change or improve the volunteer literacy program.

Like you, we are concerned with the illiteracy problem and with your cooperation, hope to discover ways to improve our service. Your prompt attention to this questionnaire will be greatly appreciated. All individual replies will remain confidential. Please return the questionnaire in the enclosed envelope as soon as possible.

A summary of the results will be published in the July newsletter. The complete study will also be available at the Iaubach office.

Thank you for your help, Masua Schirebent Kathy whittle 
Please answer all questions that pertain to you. If more space is required, use the reverse side and put the number of the question beside your answer. We welcome all comments.

I Personal Information

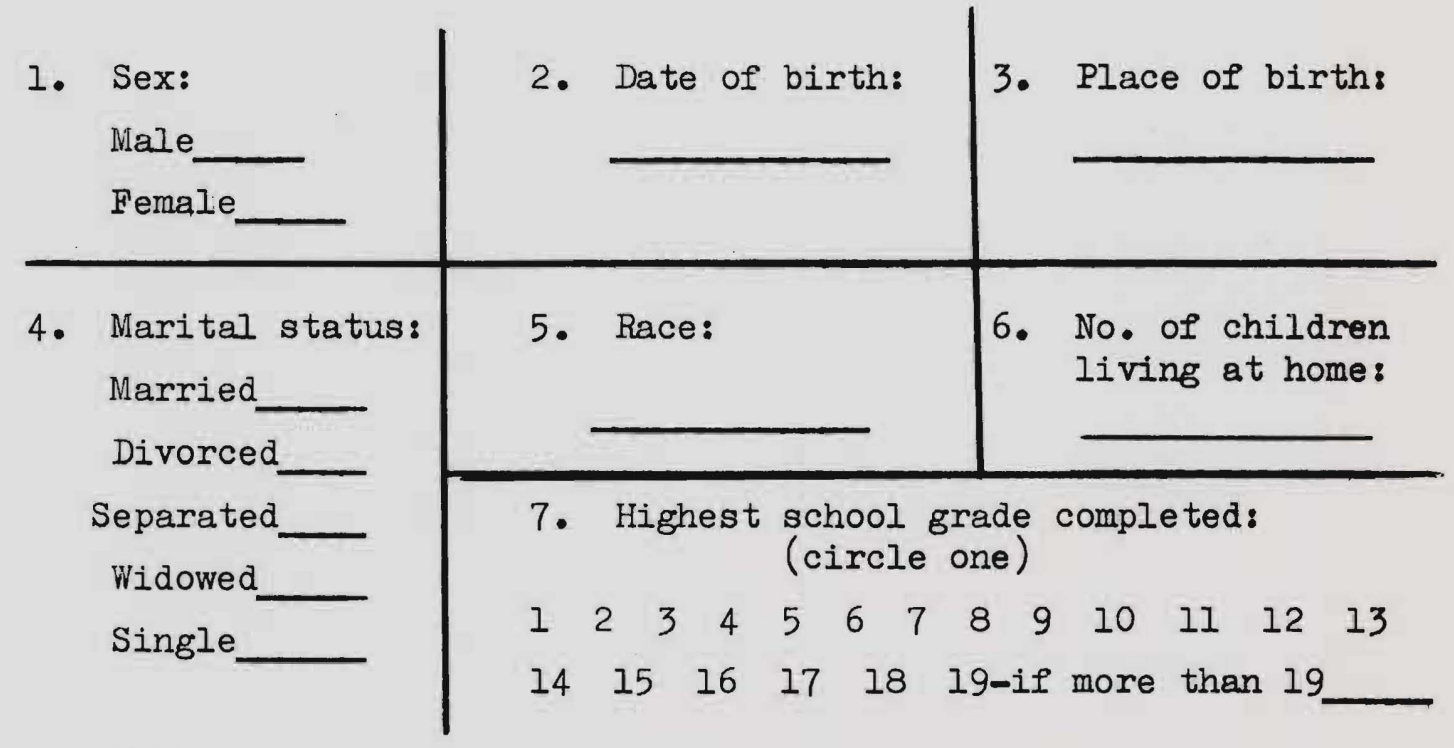

II Occupational Information

8. What degrees, if any, do you hold:

9. The following information is considered personal by some people. We are requesting it in order to compare Portland tutors with the National Study.. Please estimate your personal income and your family income to the nearest thousand per year.

Personal income Family income

10. Have you ever held a full-time job (at least 35 hours per week): Yes No

11. If you have, how long did you work: (State the amount in years and months.) 
12. What is your current employment status:

Full time Part time Looking for work

Retired Student Housewife

Other (specify)

13. If now working, what is your job title:

14. Did you have any kind of experience teaching adults before you became a volunteer tutor:

Yes __ Professional ___ Non-professional

No

15. Have you ever taught in any school professionally: Yes No

16. Are you teaching professionally now:

Yes No

If yes please indicate what type of teaching you do: Elementary Secondary Special Education College Adult Basic Education

English as Second Language Other (specify)

III Volunteers

17. How did you first learn of volunteer literacy works

18. What would you say is the main reason you became interested in volunteer literacy work: 
19. What radio station do you most often listen tos

20. What newspapers do you read regularly:

21. What TV news programs do you watch:

22. Do you feel that the Oregon Iiteracy Brogram is publicized enough to attract volunteer tutors: Yes__ No __ Not sure to attract students: Yes No __ Not sure

23. Do you have any suggestions for improving the publicity:

24. When did you become a certified Laubach tutor:

25. If you did not complete the training workshop, why not:

26. Do you feel that you had enough training to tutor adequately: Yes ___ No N_ Not sure

27. Would you like:
A refresher workshop:
Yes
No
Not sure
An advanced workshop
Yes
No
Not sure
with more emphasis on
Skill Books 4 and 5:
Informal meetings with Yes
other Laubach tutors:
No
Not sure
Individual help with Yes
No
Not sure
tutoring problems:
Yes

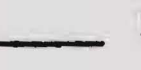
Training in learning Yes
No
Not sure
disabilities: 
28. Are you using your training in any other way (eg. teaching a class of students rather than tutoring one-to-one, or using what you have learmed to teach your children. Please explain.)

29. After completing the workshop, how soon did you begin tutoring: Under one month

Over one month

Have never tutored a student

30. If you have never tutored, could you tell us why:

If you answered question number 30 STOP HERE and return the questionnaire to us. Thank you for your help.

31. How long have you worked as a volunteer tutor:

Years Months

32. How many students have you taught in your entire volunteer teaching career:

33. How many students did you tutor last year:

34. How many students are you tutoring now:

35. If you have tutored in the past, but are not tutoring now, please explain why: 
36. Please answer the following questions for each student you are tutoring now. Use the back if you have more than two students. If you are not tutoring now, please go to question number 37.

Student 1

How long have you been tutoring your student:

Student's age:

sex:

race:

Marital status :

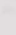
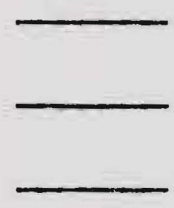

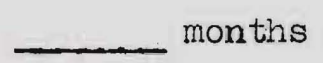

Student 2

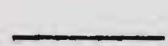

What Skill Book is your

student using:

Where do you meet:

How often do you meet

with your student:

How did your student

hear about the program:
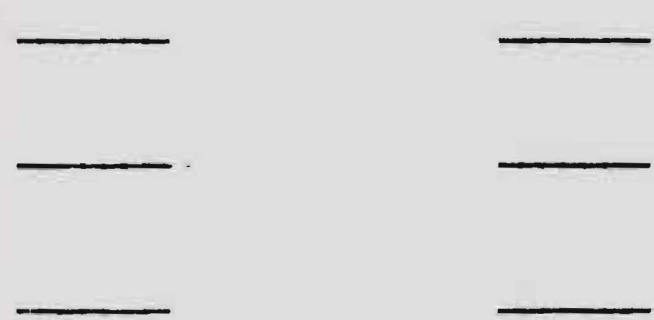

months

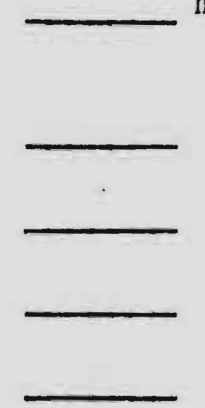

37. Did your students ever need help not related to reading eg. counseling, et,c.):

Yes _ No

If YES,

were you able to refer them to other resources:

Yes

No

38. Do you need more information on making referrals:

Yes __ No

I need information on: Medical and Dental

Welfare

Counse].ing

Employment

Housing

Food Stamps

Other (specify) 
39. How many of your past students would you estimate have progressed to the following Sikill Books:

1 2 3 4 5

40. Please estimate how many of your students dropped out for the following reasons:

Moved away Lost interest

Were not learning Progress was too slow

otror (Specify)

41. How do you feel your experience as a volunteer tutor has been in che following areas:

Please rate your experiences on the scale by placing a in the section most closely descriptive of your feeling, eg. if your experiences have been very rewarding, check the far right section.

A. The personal contact with students has been:

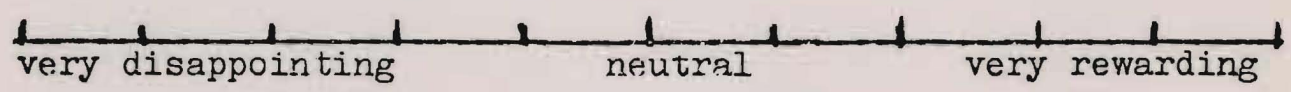

B. The result of my tutoring has been:

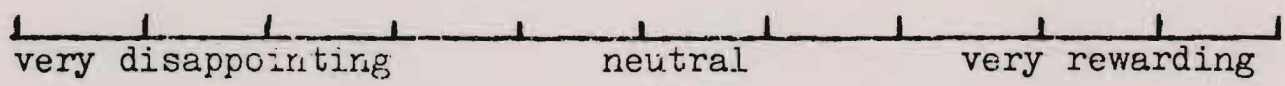

C. The contact with the Iiteracy program peopie has been:

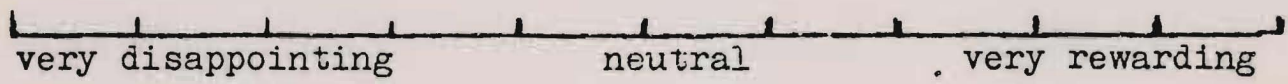

42. What could the Laubach program do to make tutoring easier for you:

43. Please comment on any changes in the program you would like to see made:

Thank you for your help. Please return immediately. 